\title{
Peptide Nucleic Acids and Biosensor Technology for Real-Time Detection of the Cystic Fibrosis W1282X Mutation by Surface Plasmon Resonance
}

\author{
Giordana Feriotto, Roberto Corradini, Stefano Sforza, Nicoletta Bianchi, \\ Carlo Mischiati, Rosangela Marchelli, and Roberto Gambari
}

Biotechnology Center (GF, RG), Ferrara University, Ferrara; Department of Organic and Industrial Chemistry (RC, SS, RM), Parma University, Parma; and Department of Biochemistry and Molecular Biology (NB, CM, RG), Ferrara University, Ferrara, Italy

\begin{abstract}
SUMMARY: In this paper we demonstrate that peptide nucleic acids (PNAs) are excellent probes able to detect the W1282X point mutation of the cystic fibrosis (CF) gene when biospecific interaction analysis (BIA) by surface plasmon resonance (SPR) and biosensor technologies is performed. The results reported here suggest that BIA is an easy, fast, and automatable approach for detecting mutations of CF, allowing real-time monitoring of hybridization between 9-mer CF PNA probes and target biotinylated PCR products generated from healthy, heterozygous subjects and homozygous W1282X samples and immobilized on streptavidin-coated sensor chips. This method is, to our knowledge, the first application of PNAs, BIA, and SPR to a human hereditary mutation, and demonstrates the feasibility of these approaches for discriminating between normal and mutated target DNA. We like to point out that the procedure described in this paper is rapid and informative; results are obtained within a few minutes. This could be of great interest for molecular pre-implantation diagnosis to discriminate homozygous CF embryos from heterozygous and healthy embryos. Other advantages of the methodology described in the present paper are (a) that it is a nonradioactive methodology and (b) that gel electrophoresis and/or dot-spot analysis are not required. More importantly, the demonstration that SPR-based BIA could be associated with microarray technology allows us to hypothesize that the method described in the present paper could be used for the development of a protocol employing multispotting on SPR biosensors of many CF-PCR products and a real-time simultaneous analysis of hybridization to PNA probes. These results are in line with the concept that SPR could be an integral part of a fully automated diagnostic system based on the use of laboratory workstations, biosensors, and arrayed biosensors for DNA isolation, preparation of PCR reactions, and identification of point mutations. (Lab Invest 2001, 81:1415-1427).
\end{abstract}

$T$ he recent development of biosensor technologies for biospecific interaction analysis (BIA) (Jonsson et al, 1991; Malmqvist, 1993; Vadgama and Crump, 1992) enables us to monitor DNA-DNA and DNA-RNA hybridization in real time by surface plasmon resonance (SPR). This optical technique detects and quantifies changes in refractive index in the vicinity of the surface of sensor chips to which either target DNA or DNA probes could be immobilized (Malmqvist, 1993). Because the changes in refractive index are proportional to the changes in absorbed mass (Malmqvist, 1993; Vadgama and Crump, 1992), the SPR technology allows the monitoring of DNA-DNA hybridization while it is occurring (Nilsson et al, 1995; Wood, 1993). Therefore SPR-based BIA has been

Received June 14, 2001.

This research was supported by Ministero della Sanità, Italy, by Ministero dell'Universitá e della Ricerca Scientifica e Tecnologica (MURST COFIN98) and by the National Research Council (target project "Biotechnology"). The BIAcore-1000 10 was obtained with a grant from the "Grandi attrezzature ad uso comune" fund of the Ferrara University.

Address reprint requests to: Prof. Roberto Gambari, Department of Biochemistry and Molecular Biology, Via L. Borsari n.46, 44100 Ferrara, Italy.E-mail:gam@dns.unife.it applied to detect HIV-1 infection (Bianchi et al, 1993, 1997) and genetic mutations affecting the p53 oncosuppressor gene (Nilsson et al, 1997). Despite the fact that this approach could be of great interest in clinical genetics (Bianchi et al, 1993; Jenkins, 1994), few data in the literature are available on the use of SPR and biosensor technologies to discriminate between the homozygous and heterozygous states in the case of hereditary diseases caused by genetic mutations (Feriotto et al, 1999; Nilsson et al, 1997).

In this respect, peptide nucleic acids (PNAs) (Nielsen et al, 1991) are molecules of great interest, because they offer great advantages, in comparison with oligonucleotide probes, in molecular diagnosis (Dueholm and Nielsen, 1997; Hyrup and Nielsen, 1996; Wang, 1998). PNAs are DNA mimics in which the sugar-phosphate backbone is replaced by $\mathrm{N}-(2-$ aminoethyl)glycine units (Nielsen et al, 1991) and hybridize with complementary DNA, forming WatsonCrick double helices (Egholm et al, 1992, 1993). We emphasize that the efficiency of PNA-DNA hybridization is very high. For instance, unlike oligodeoxyribonucleotide probes, very short PNAs are still able to hybridize at room temperature because the melting temperature (Tm) of PNA-DNA hybrids is higher than 
that of DNA-DNA hybrids (Nielsen and Egholm, 1999). This feature is expected to greatly facilitate detection of point mutations (Nielsen and Egholm, 1999). With respect to this point, it is known (Feriotto et al, 1999) that 15- to 20-bp long oligonucleotide probes do not efficiently discriminate between target sequences that differ by one oligonucleotide in BIA experiments employing surface plasmon resonance and biosensor technology (Feriotto et al, 1999). Shorter oligonucleotides could be used, but in that case the hybridization reaction could be inefficient because of the lower number of hydrogen bonds. By contrast, even short PNAs are expected to be efficient in hybridizing to target DNA, because they are not negatively charged and, therefore, no electrostatic repulsion occurs during PNA-DNA hybrid formation (Wittung et al, 1994). In addition, unlike oligonucleotides, PNAs are expected to bind with high efficiency to single-stranded PCR products, because their binding could be independent from the secondary structure of target DNA (Nielsen and Egholm, 1999). Furthermore, the stability of PNADNA hybrids is greatly affected by the presence of a single base mismatch (Jensen et al, 1997). This property has been used for the detection of point mutations in advanced diagnostic methods, by means of PCR clamping (Ørum et al, 1993), affinity electrophoresis (Igloi, 1999), matrix-assisted laser desorption/ionization time-of-flight mass spectrometry (Griffin et al, 1997), electrochemical biosensors (Wang, 1998, Wang et al, 1997b), quartz crystal microbalance (QCM) (Wang et al, 1997a), and microarrays (Weiler et al, 1997).

In this paper we describe the use of PNA probes for SPR-based BIA in the detection of the tryptophan $1282 \rightarrow$ TER mutation of the cystic fibrosis (CF) transmembrane conductance regulator (CFTR) gene (Online Mendelian Inheritance in Man: database entry no. 602421, according to Antonarakis [1998]). This hereditary pathology is the most frequent recessive autosomal lethal disease in the Caucasian population (Boat et al, 1989). In addition to microdeletions, CF is due to a variety of point mutations. The W1282X mutation, located in exon 20, was first observed in a French patient with cystic fibrosis by Vidaud et al (1990) and was demonstrated to be the most common CF mutation in the Ashkenazi Jewish population (Shoshani et al, 1992).

Mutations leading to the CF phenotype are currently detected by a variety of PCR-based approaches (Saiki et al, 1985), including single-strand conformation polymorphism (SSCP/HA) (Wine et al, 2001), temporal temperature gradient gel electrophoresis (TTGE) (Wong et al, 2000), DNA sequencing (Bernardino et al, 2000), oligonucleotide ligation assay (OLA), sequencecoded separation (Brinson et al, 1997), and capillary zone electrophoresis combined with laser-induced fluorescence detection (Gelfi et al, 1998). Although highly informative and successfully applied in the diagnosis of CF, some of these methodologies are tedious, technically complex, sometimes difficult to use routinely in a clinical context, when the most important requirements are quality of service, speed, accuracy, and transferability to high-throughput formats (Shi, 2001).

\section{Results}

Melting Temperatures of PNA N-W1282X and M-W1282X with Complementary and Mismatched DNA Targets

To determine the DNA recognition stability and specificity of PNA N-W1282X and PNA M-W1282X, hybrid solutions were formed between either PNA and the full complementary or the mismatched DNA sequences (Fig. 1): PNA N-W1282X/DNA 5'-AGTGGAGGA-3' (full match), PNA M-W1282X/DNA 5'-AGTGAAGGA-3' (full match), PNA N-W1282X/DNA 5'-AGTGAAGGA-3' (mismatch), and PNA M-W1282X/DNA 5'-AGTGGAGGA-3' (mismatch). The solutions were heated and the absorbance was measured to obtain melting curves. The melting temperatures were calculated as the maximum of the first derivatives of the melting curves. The results are reported in Figure 2 . The data clearly indicate that both PNAs clearly recognize the complementary DNA, because the stability of both PNA-DNA duplexes drop off $10^{\circ} \mathrm{C}$ in the presence of a single mismatch in the central part of the sequence of the DNA in agreement with data in the literature (Jensen et al, 1997). The difference of $4^{\circ} \mathrm{C}$ between the two fully matched complexes can be ascribed to the different sequence of the PNAs, which leads to a different stability of the PNADNA duplexes. In fact, the PNA M-W1282X/DNA duplex has an A-T base pair (two hydrogen bonds) in place of the G-C base pair (three hydrogen bonds) present in the PNA N-W1282X/DNA duplex.

\section{Hybridization of N-W1282X and M-W1282 DNA and PNA Probes to Mutated W1282X 21-mer Target DNA: BIA Analysis}

In Figure 3 a scheme depicting DNA-DNA and DNAPNA hybrids is reported (Fig. 3A), along with the experimental approach followed to study both the formation and stability of these complexes under BIA experimental conditions (Fig. 3B). As a general strategy, we chose to immobilize target biotinylated DNA and use PNA as probes, because in kinetic studies (Jensen et al, 1997) it was reported that immobilization of PNA led to a decrease of one order of magnitude of the association rate constant. As is clearly evident (Fig. 3C), both N-W1282X and M-W1282X 17-mers DNA probes do hybridize to the target M-W1282X DNA generating stable DNA-DNA hybrids. In addition, the data obtained show that both N-W1282X and $\mathrm{M}-\mathrm{W} 1282 \mathrm{X}$ 12-mers probes hybridize to the target M-W1282X DNA (Fig. 3D). In this case, however, only fully matched hybrids are stable (Fig. 3D, solid line). By contrast, when 9-mers probes are employed, only the M-W1282X DNA was found to hybridize to full complementary M-W1282X 21-mer target DNA, generating, however, unstable hybrids (Fig. 3E, solid line). Taken together, these preliminary experiments demonstrate that both 9-mer and 12-mer DNA probes are expected to be suitable for identification of the W1282X mutation. However, differences among these 


\title{
CFTR gene
}

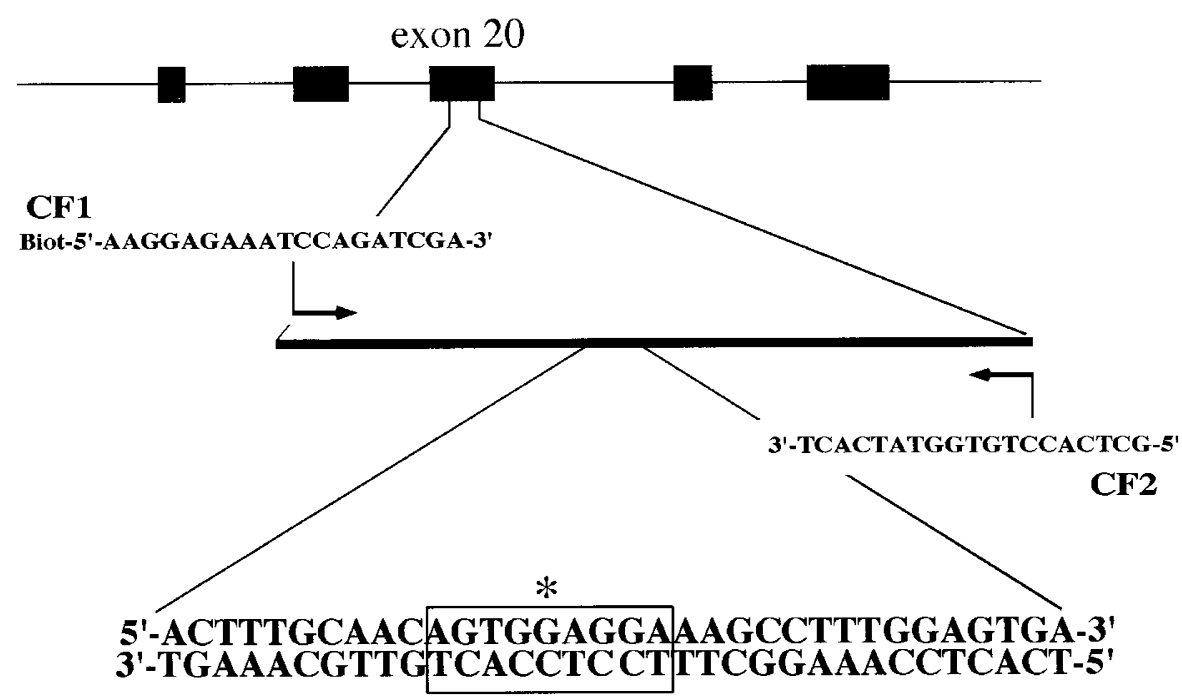

$\mathbf{T}$

L Q

Q W

R K

$\begin{array}{llll}\text { A } & \text { F } & \text { G } & \text { V }\end{array}$

\author{
Biotinylated \\ 5'-Biot-AGTGGAGGA-3' \\ target DNA \\ 5'-Biot-AGTGAAGGA-3' \\ 5'-Biot-TGCAACAGTGAAGGAAAGCCT-3'
}

\begin{tabular}{|c|c|c|}
\hline \multirow{3}{*}{ DNA probes } & $\begin{array}{l}\text { 5'-GCTTTCCTCCACTGTTG-3' } \\
\text { 5'-TTTCCTCCACTG-3' } \\
\text { 5'-TCСТCСАCT-3' }\end{array}$ & $\begin{array}{l}\text { N-W1282X-DNA-17 } \\
\text { N-W1282X-DNA-12 } \\
\text { N-W1282X-DNA-9 }\end{array}$ \\
\hline & 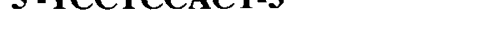 & \\
\hline & $\begin{array}{l}\text { 5'-GCTTTCCTTCACTGTTG-3' } \\
\text { 5'-TTTCCTTCACTG-3' } \\
\text { 5'-TCСTTCACT-3' }\end{array}$ & $\begin{array}{l}\text { M-W1282X-DNA-17 } \\
\text { M-W1282X-DNA-12 } \\
\text { M-W1282X-DNA-9 }\end{array}$ \\
\hline PNA probes & $\begin{array}{l}\text { H-TCCTCCACT-NH } \\
\text { H-TCCTTCACT-NH } \\
2\end{array}$ & $\begin{array}{l}\text { N-W1282X-PNA-9 } \\
\text { M-W1282X-PNA-9 }\end{array}$ \\
\hline
\end{tabular}

Figure 1.

Map of the cystic fibrosis (CF) transmembrane conductance regulator (CFTR) gene region involved in the W1282X mutation causing CF and location of the CF1 (forward) and CF2 (reverse) PCR primers. The nucleotide sequences of the biotinylated target W1282X 9- and 21-mers injected overflow cells of SA5 sensor chips are indicated. The sequences of DNA and peptide nucleic acid (PNA) probes are also indicated.

probes are reproducibly detectable. In fact, the use of short DNA probes (9-mer) allows us to identify the W1282X mutation during the association phase (compare the values of RUfin-RUi reported in Table 1). On the contrary, longer DNA probes (12-13 mers) allow us to identify the mutation during the dissociation phase (compare the values of RUres-RUi reported in Table 1). Under the BIA experimental conditions employed, 17-mer DNA probes are not useful for identification of the CF mutation (Fig. 3C and Table 1).

In the experiment shown in Figure 4, the hybridization behavior of 9-mer PNA probes (Fig. 4, A to C) was compared to that of 9-mer (Fig. 4, D to F) and 12-mer (Fig. 4, G to I) DNA probes. Interestingly, both the N-W1282X and M-W1282X PNAs hybridize to the full complementary target DNAs (Fig. 4, A and $B)$. In this case, hybridization is much more efficient than that of the 9-mer DNA probes, and the generated PNA-DNA hybrids are much more stable than DNA-DNA hybrids (Fig. 4, A, B, D, and E). No hybridization occurs between mismatched PNA probes and target W1282X DNA (Fig. 4, A and B). Also, 9-mer PNA probes (Fig. 4, A to C) are more efficient than 12-mer DNA probes (Fig. 4, G to I), as judged by comparing the RUfin-RUi values obtained with PNA probes with the RUres-RUi values ob- 

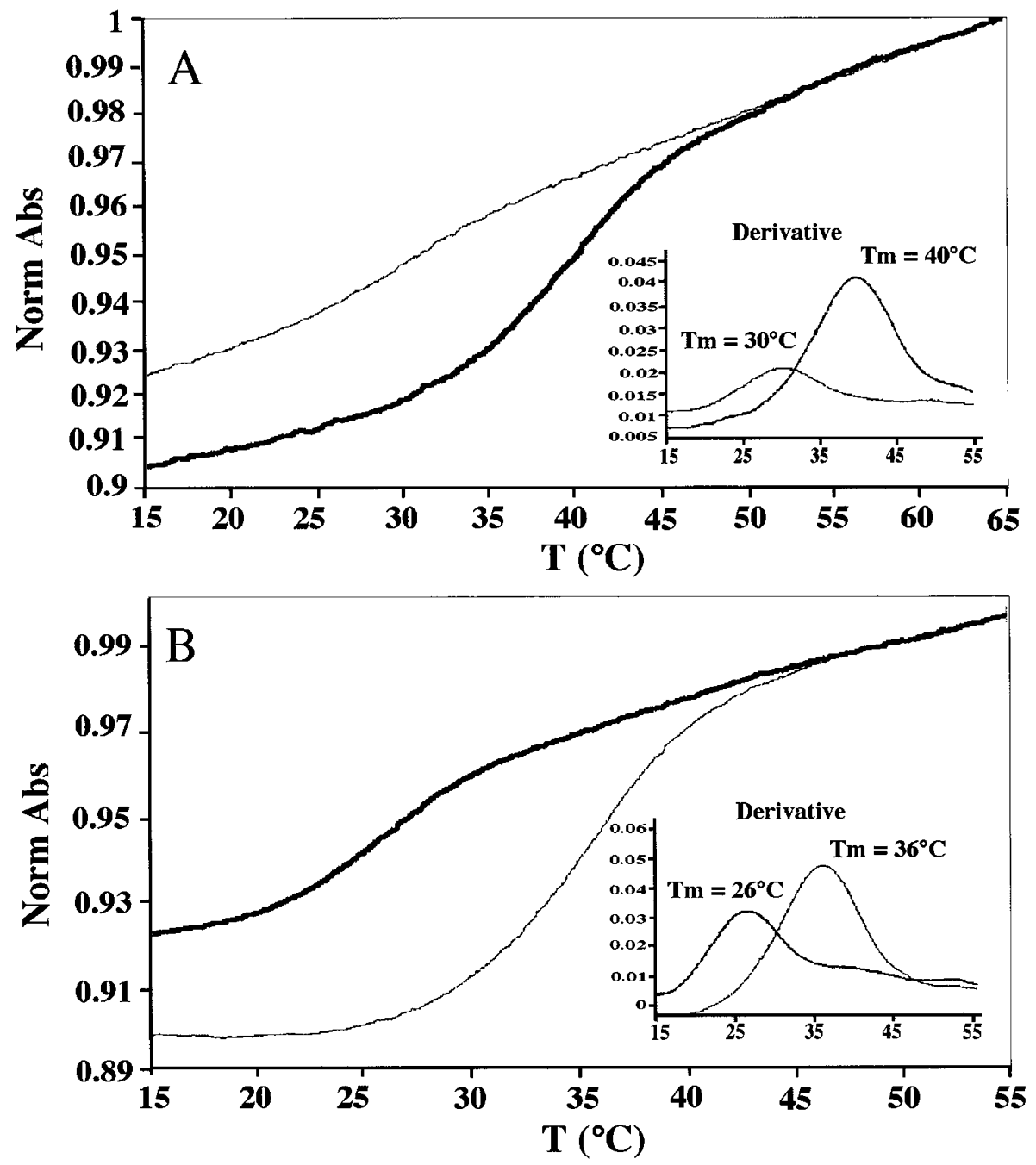

Figure 2.

Melting curves and melting temperatures of (A) N-W1282X 9-mer PNA hybridized with the DNA 5'-AGTGGAGGA-3' (thick line, full match) and with the DNA 5'-AGTGAAGGA-3' (thin line, mismatch). B, M-W1282X 9-mer PNA hybridized with the DNA 5'-AGTGAAGGA-3' (thin line, full match) and with the DNA 5'-AGTGGAGGA-3' (thick line, mismatch).

tained with 12-mer DNA probes. Taken together, these results suggest that PNAs are able to identify efficiently the cystic fibrosis W1282X DNA mutation when a target oligonucleotide DNA is employed.

\section{Interaction of N-W1282X and M-W1282 DNA and PNA Probes with Sensor Chips Carrying a 1:1 Mixture of Normal and Mutated Target DNA Sequences}

In Figure 4, C, F, and I, we report the sensorgrams obtained by injecting N-W1282X and M-W1282X DNA and PNA probes on a same flow cell carrying a 1:1 mixture of both normal and mutated W1282X target sequences. As clearly evident, both N-W1282X and M-W1282X DNA and PNA 9-mer probes hybridize to the SA5 sensor chip flow cell containing a 1:1 mixture of target N-W1282X and M-W1282X DNA sequences (Fig. 4, C and F). In addition, the 12-mer N-W1282X and M-W1282X DNA probes, as expected, give rise to hybrids exhibiting similar RUres-RUi values (Fig. 4I).
The RUfin-RUi and RUres-RUi values are shown in Table 2.

\section{Immobilization on a SA5 Sensor Chip of Target CF PCR Products from a Normal Subject or Heterozygous and Homozygous W1282X CF Samples}

Figure 1 shows the location of the CF2 end 5'biotinylated CF1 PCR primers within the exon 20 portion of the CFTR gene (Riordan et al, 1989). Double-stranded target CFTR gene PCR products were produced using an excess of the CF2 primer with respect to the biotinylated CF1 primer. This was done to minimize the presence of the biotinylated, unincorporated CF1 PCR primer in the PCR mixture. The final PCR product was, in any case, further purified by Microcon-30. PCR was performed using as substrates DNA from normal individuals, as well as from heterozygous and homozygous W1282X samples. Figure $5 \mathrm{~A}$ shows the immobilization of bio- 


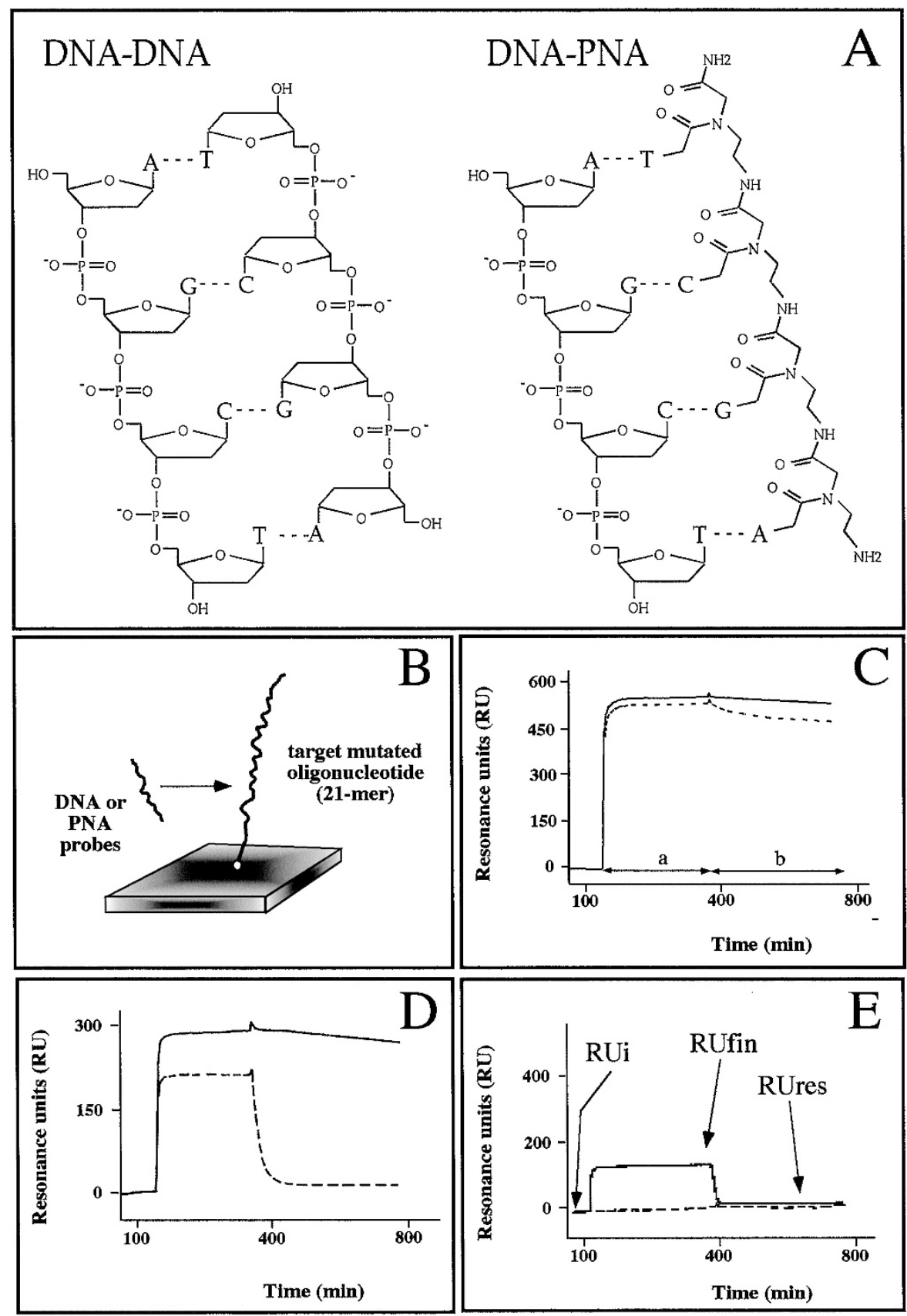

Figure 3.

A, Scheme of DNA-DNA and DNA-PNA hybrids. B, Experimental strategy. C to E, Sensorgrams obtained after injection on a flow cell carrying M-W1282X 21-mer target DNA of $25 \mu \mathrm{l}$ containing $0.5 \mu \mathrm{g}$ of normal (dotted lines) and mutated (solid lines) W1282X 17-mer (C), 12-mer (D), and 9-mer (E) DNA probes. The oligonucleotide probes were dissolved in HEPES buffered saline-EP (HBS-EP). a, injection of the oligonucleotide probes; $b$, injection of HBS-EP.

tinylated CF1-CF2 PCR products on a SA5 sensor chip. As is evident, the binding kinetic is slow (Fig. 5A, segment "a" of the sensorgram); after a 30- $\mu$ l pulse of the CF2/CF3 biotinylated PCR product (approximately $10 \mu \mathrm{g} / 50 \mu \mathrm{l}$ HEPES buffered saline-EP [HBS-EP] buffer), no plateau levels of RUfin are reached. In any case, as expected, the regeneration step with $50 \mathrm{~mm}$ $\mathrm{NaOH}$ (Fig. 5A, segment "c" of the sensorgram) induced a decrease of the RUfin by approximately $50 \%$, which was the RUres still present on the flow cell because the ssPCR product stably immobilized on the sensor chip. Figure $5 \mathrm{~B}$ shows the levels of RUres obtained after four injections of biotinylated CF1-CF2 PCR product. Figure 5B shows the immobilization of biotinylated PCR product using as substrate DNA from normal, heterozygous, or homozygous W1282X samples. The quality of PCR products was checked by agarose gel electrophoresis (Fig. 5B, insert) and direct DNA sequencing (data not shown). Repeated injections of CF1-CF2 biotinylated PCR product were performed to reach saturation of streptavidin binding sites of the flow cell. 
Table 1. Comparison of the Hybridization Efficiency of 9-mer, 12-mer, and 17-mer DNA Probes

\begin{tabular}{lcccc}
\hline & \multicolumn{3}{c}{ Target: M-W1282X 21-mer } \\
\cline { 2 - 5 } W1282X probe & 2 & N-W1282X & \multicolumn{2}{c}{ M-W1282X } \\
\cline { 2 - 5 } \cline { 2 - 5 } RUfin-RUi & RUres-RUi & & RUfin-RUi & RUres-RUi \\
\hline 9-mer & 197 & 5 & 145 & 13 \\
12-mer & 556 & 509 & 569 & 242 \\
17-mer & & & & 550 \\
\hline
\end{tabular}

Hybridization between the W1282X DNA and PNA Probes and Biotinylated PCR Immobilized on a SA5 Sensor Chip

The binding efficiency of the W1282X 9-mer DNA, 12-mer DNA, and 9-mer PNA probes to the CF1/CF2 PCR products is shown in Figure 6. Figure 6, A and B, shows a preliminary analysis of the expected secondary structures of the immobilized PCR products. This was analyzed by using the MFOLD software (version 3.0) developed by Zuker et al (1999), and Mathews et al (1999). The analysis was performed at a temperature of $25^{\circ} \mathrm{C}$ and at $0.15 \mathrm{M} \mathrm{NaCl}$. The data obtained demonstrate that the CF W1282X PCR products are able to generate secondary structures (Fig. 6, A and B). Figure $6 \mathrm{C}$ shows the experimental strategy, which consists of immobilization of PCR products (as shown in Fig. 5) and injections of CF W1282X DNA and PNA probes, as shown in Figure 4. The results reported in Figure 6, D to $F$, show that very weak binding of both $\mathrm{N}-\mathrm{W} 1282 \mathrm{X}$ (dotted lines) and M-W1282X (solid lines) 9-mer probes is detectable, even to the full complementary PCR product. On the contrary, the W1282X 9-mer PNA probes are able to generate hybrids, leading to an evident increase in RUfin and RUres values only in the case of hybridization between PNA probes and fully matched target PCR products (Fig. 6, $G$ to I). These results clearly indicate that the W1282X 9-mer PNAs are efficient probes for generating hybrids with target $\mathrm{PCR}$ products.

Figure $6, \mathrm{~L}$ to $\mathrm{N}$, shows that both the 12-mer N-W1282X and M-W1282X DNA probes hybridize to immobilized PCR products from normal (Fig. 6L), heterozygous (Fig. 6M) or homozygous (Fig. 6N) samples (similar values of RUfin-RUi are obtained). However, as judged by looking at the RUres-RUi values, only fully matched hybrids are stable. After comparison of the RUfin-RUi values of Figure 6, Panels G to I, and RUres-RUi values of Figure 6, Panels $L$ to $N$, it is quite evident that 9-mer PNA probes are more efficient than 12-mer DNA probes in recognizing fully matched target PCR products.

The lack of hybridization between PCR products immobilized on the SA5 sensor chip and the 9-mer DNA probes could be explained by the possibility that single-stranded PCR products may generate secondary structures (Fig. 6, A and B). Therefore, when short DNA probes are injected into SA5 sensor chips carrying PCR products, hybridization might be inefficient because of the formation of secondary structures of the target DNA (this hypothesis is depicted in Fig. 6C).

\section{PNA Probes in Molecular Diagnosis of W1282X Cystic Fibrosis}

To verify whether PNAs might be used as probes for molecular diagnosis of W1282X cystic fibrosis, we determined the "cystic fibrosis index" (CF index) as the value (RUfin-RUi)(N)/(RUfin-RUi)(M), where (RUfin-RUi)(N) are the values obtained with the N-W1282X PNA probe and the (RUfin-RUi)(M) values are those obtained with the M-W1282X PNA probes (Table 3). The CF index was found to be high $(4.3 \pm 0.8)$ when PCR products from normal subjects were used. On the contrary, this value approached $1(1.05 \pm 0.35)$ when PCR products from heterozygous W1282X subjects were used. Finally, the CF index was found always to be lower than $0.5(0.28 \pm 0.1)$ when PCR products from homozygous $\mathrm{W} 1282 \mathrm{X}$ samples were immobilized on the SA5 sensor chip. These data allow us to conclude that 9-mer PNAs probes are useful for molecular diagnosis of W1282X cystic fibrosis.

\section{Sensitivity of PNA Probes in Detecting M-W1282X PCR Products}

We first prepared SA5 sensor chips carrying different concentrations of M-W1282X PCR products (100\%, $50 \%, 20 \%, 10 \%, 5 \%$, and $0 \%)$. This was achieved by suitably mixing N-W1282X and M-W1282X biotinylated PCR products and injecting the mixture on different flow cells as previously illustrated in Figure 5. When the 9-mer M-W1282X PNA probe was injected, we found that the RUfin-RUi values decreased, as expected, in relation to the decrease of the percentage of M-W1282X PCR product. Although clear hybridization is detectable when the 9-mer M-W1282X PNA probe is injected into mixtures containing $100 \%$, $50 \%$, and $20 \% \mathrm{M}-\mathrm{W} 1282 \mathrm{X}$ PCR product, the RUfinRUi values obtained on $10 \%$ and $5 \%$ mixtures were found to be only slightly higher than the background values obtained by injecting the PNA probe onto a sensor chip containing only the N-W1282X PCR product (Table 4).

\section{Discussion}

In this paper we demonstrate that PNAs (Nielsen et al, 1991) are excellent probes for detecting the W1282X point mutations of the cystic fibrosis (CF) gene when BIA by SPR (Malmqvist, 1993) and biosensor technologies is performed. The results reported here suggest that BIA is an easy, fast, and automatable approach to 


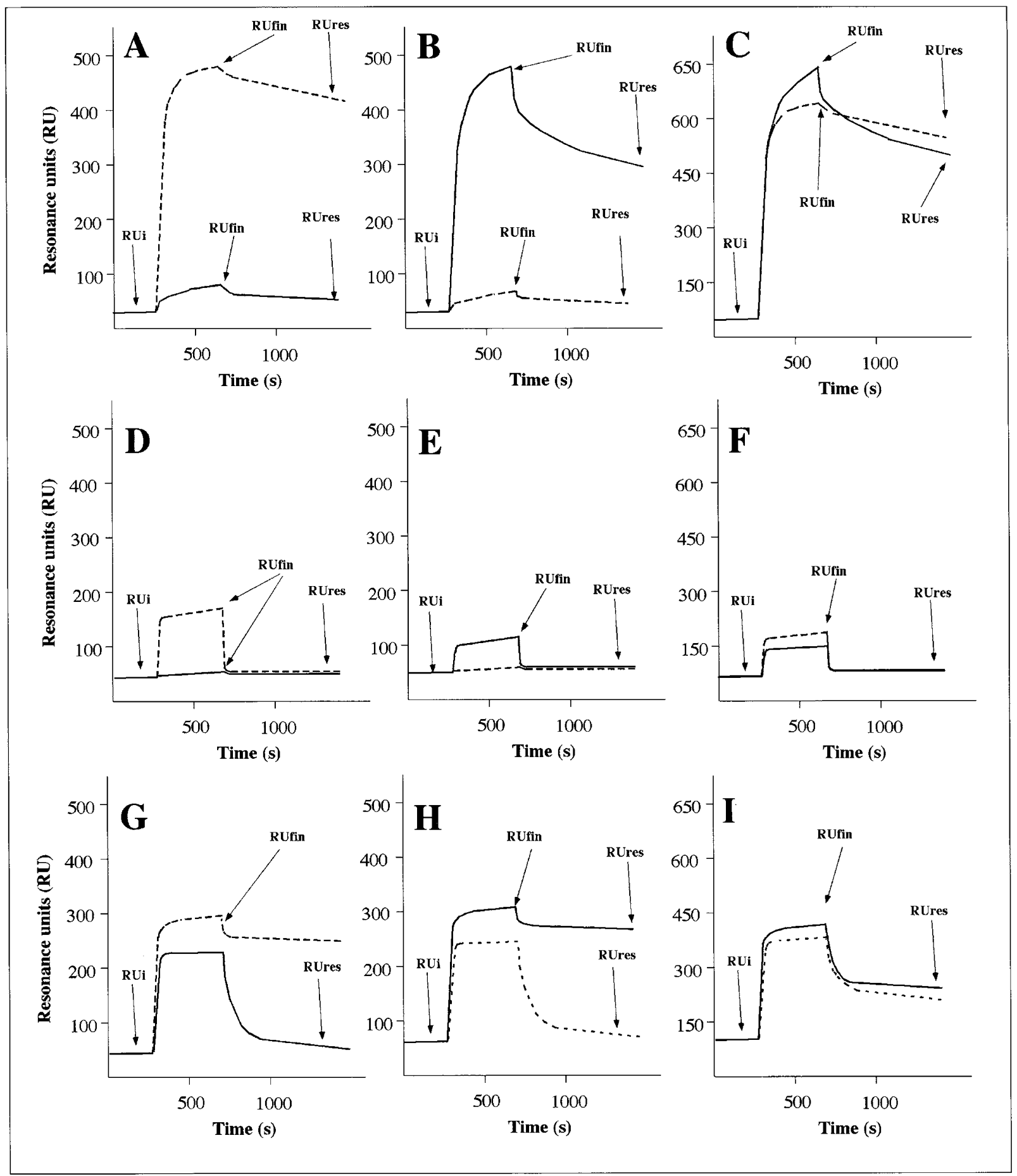

Figure 4.

Sensorgrams obtained after injection of $25 \mu \mathrm{l}$ containing $0.5 \mu \mathrm{g}$ of normal (dotted lines) and mutated (solid line) W1282X 9-mer PNA (A-C), 9-mer DNA (D-F), and 12-mer DNA (G-I) probes to SA5 sensor chip flow cells carrying normal (A, D, G) or mutated (B, E, H) W1282X 12-mer target DNA. In Panels C, F, and I, the probes were injected to a flow cell carrying a 1:1 mixture of normal and mutated W1282X 12-mer target DNA. The oligonucleotide probes were dissolved in HBS-EP.

detecting mutations of $\mathrm{CF}$, allowing real-time monitoring of hybridization between CF PNA probes and target biotinylated PCR products generated from normal, heterozygous, and homozygous W1282X samples and immobilized on streptavidin-coated sensor chips.

During the association phase, carried out with HBS-EP at $25^{\circ} \mathrm{C}$, discrimination between mis- matched and fully matched PNA/DNA hybrids is readily and reproducibly observed by analyzing the association phases of the sensorgrams. By sharp contrast, in the same experimental conditions, the 9-mer DNA probe was not able to efficiently hybridize to PCR products. In addition, PNA probes were shown to be more efficient than 12-mer DNA probes, which are able to identify W1282X point mutation during the 
Table 2. Comparison of the Hybridization Efficiency of 9-mer and 12-mer DNA and PNA Probes

\begin{tabular}{|c|c|c|c|c|c|c|}
\hline \multirow[b]{3}{*}{ W1282X probe } & \multicolumn{6}{|c|}{ Target: N-W1282X and M-W1282X 12-mers } \\
\hline & \multicolumn{2}{|c|}{$N-W 1282 X$} & \multicolumn{2}{|c|}{ M-W1282X } & \multicolumn{2}{|c|}{$\begin{array}{c}\mathrm{N}-\mathrm{W} 1282 \mathrm{X}: \mathrm{M}-\mathrm{W} 1282 \mathrm{X} \\
(1: 1)\end{array}$} \\
\hline & RUfin-RUi & RUres-RUi & RUfin-RUi & RUres-RUi & RUfin-RUi & RUres-RUi \\
\hline \multicolumn{7}{|l|}{ DNA probes } \\
\hline N-W1282X 9-mer & 136 & 24 & 5 & 3 & 111 & 3 \\
\hline M-W1282X 9-mer & 2 & 2 & 81 & 2 & 78 & 2 \\
\hline N-W1282X 12-mer & 361 & 322 & 197 & 14 & 307 & 137 \\
\hline M-W1282X 12-mer & 246 & 42 & 299 & 242 & 342 & 151 \\
\hline \multicolumn{7}{|l|}{ PNA probes } \\
\hline N-W1282X 9-mer & 479 & 436 & 31 & 13 & 462 & 415 \\
\hline M-W1282X 9-mer & 45 & 28 & 429 & 306 & 598 & 426 \\
\hline
\end{tabular}

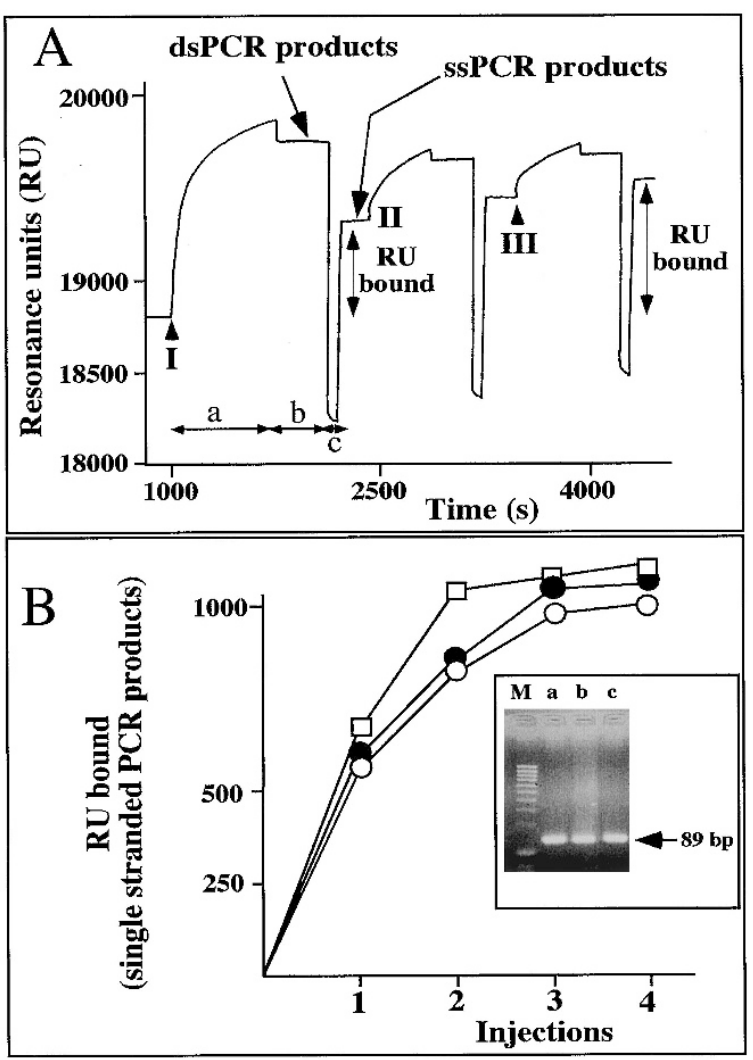

Figure 5.

A, Representative example of the increase of resonance units following injection on biotinylated CF1-CF2 PCR products from an homozygous W1282X sample. Three injections were consecutively performed (I-III). A total amount of $60 \mu \mathrm{l}$ of $2.5 \mu \mathrm{M}$ PCR products in HBS-EP was injected. After each injection (segments "a" of the panel), injections of HBS-EP (segments " $b$ " of the panel) and $50 \mathrm{~mm} \mathrm{NaOH}$ (segments "c" of the panel) were performed. No blank subtraction was performed. B, Comparison of the increase of resonance units following injection on biotinylated PCR products from normal subjects (open circles), homozygous W1282X samples (open squares), or heterozygous subjects (filled circles). Insert: Characterization by agarose gel electrophoresis of biotinylated PCR products from normal subjects (a), homozygous W1282X samples (b), or heterozygous subjects (c).

dissociation phase, reaching, however, a RUres level lower than the RUfin reached by 9-mer PNA probes.

The use of PNAs in SPR-based BIA has been recently explored by Sawata et al (1999), Kai et al
(1997), and Burgener et al (2000). Sawata et al (1999) applied PNAs to the direct detection of deoxyribonucleic acid amplified by polymerase chain reaction, demonstrating that this method is a powerful tool for the diagnosis of pathologically significant DNA. On the other hand, Burgener et al (2000) synthesized a stable and specific SPR biosensor surface employing covalently immobilized PNAs, demonstrating the ability to detect point mutations after the injection of complementary oligonucleotides.

This paper demonstrates for the first time the possible use of PNAs to efficiently identify point mutations in PCR-generated targets performing BIA using SPR and the BIAcore biosensor. Consistently, PNAs are much more efficient than DNA probes in hybridizing to immobilized PCR products (Fig. 6). This behavior could be due to the possible secondary structure of the target CF PCR (Fig. 6), leading to lower hybridization efficiency with short DNA probes. In this respect, it is known that PNAs hybridize to DNA independently of its secondary structure (Nielsen and Egholm, 1999). This method is, to our knowledge, the first application of PNAs, BIA, and SPR to a human hereditary mutation, demonstrating the feasibility of these approaches in discriminating between normal, heterozygous, and homozygous W1282X subjects.

Many diagnostic approaches have been recently introduced which are aimed at the development of high-throughput mutation detection and genotyping technologies, among which are gel-based methods such as PCR-restriction fragment length polymorphism (RFLP) (Shi et al, 1999), oligonucleotide ligation assay (OLA) (Baron et al, 1996; Eggerding, 2000; Rothschild et al, 1997), and minisequencing (Shi, 2001). However, it should be emphasized that nongel-based, high-throughput genotyping technologies are expected to be, in the near future, the dominant genotyping platforms for large-scale studies (Shi, 2001). Among non-gel-based diagnostic technologies, fluorescence resonance energy transfer (FRET) (Clegg, 1992) has been employed for FRET-based technologies such as TaqMan (Livak et al, 1995; Tapp et al, 2000) and Invader assays (Lyamichev et al, 1999), molecular beacons (Tyagi et al, 1998), FRET- 

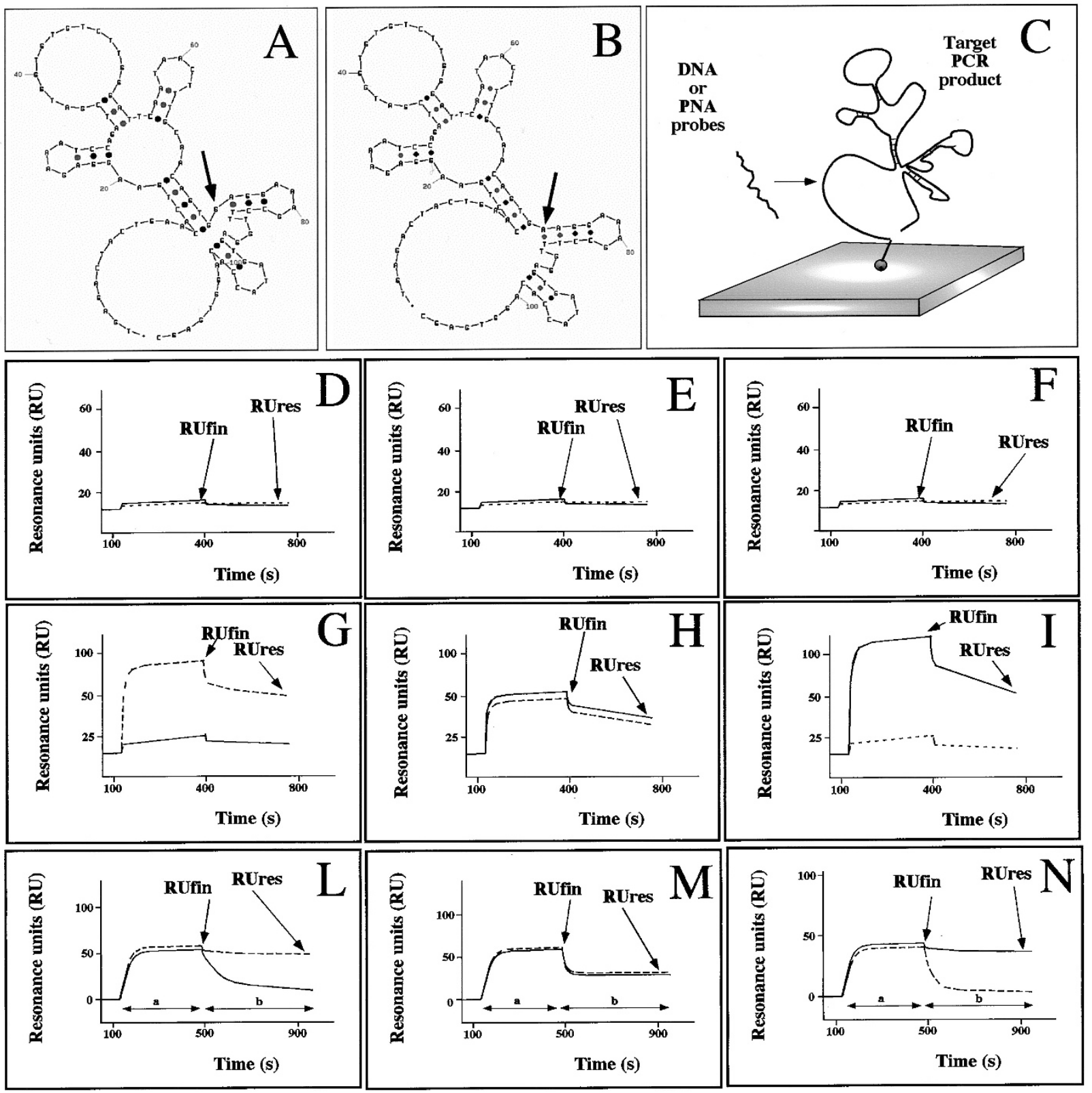

Figure 6.

A and B, Secondary structures of single-stranded CF1-CF2 CFTR PCR products carrying both normal (A) and mutated (B) W1282X sequences. The MFOLD software (version 3.0) developed by Zuker et al (1999) was used in this analysis. The experiments were performed at $25^{\circ} \mathrm{C}$ temperature and at $0.15 \mathrm{M} \mathrm{NaCl}$. The nucleotide W1282X mutation is indicated by an arrow. C, Experimental strategy. D to N, Sensorgrams obtained after injection of $25 \mu \mathrm{l}$ containing $0.5 \mu \mathrm{g}$ of normal (dotted lines) and mutated (solid lines) W1282X 9-mer DNA (D-F), 9-mer PNA (G-I), and 12-mer DNA (L-N) probes onto flow cells carrying PCR products from normal subjects $(D, G, L)$, heterozygous subjects (E, H, M), or homozygous W1282X samples (F, I, N). The probes were injected in HBS-EP. a, injection of the probes; b, injection of HBS-EP.

based PCR-OLA (Chen et al, 1998), and FRET-based rolling circle amplification (RCA)(Lizardi et al, 1998). Most of these novel diagnostic approaches have not been applied to CF mutation detection, and, therefore, a precise comparison of the efficiency of these methods with that of the approach described in our paper, despite being of great interest, is not possible at present.

However, we would like to point out that the procedure described in this paper is, to our knowledge, one of the most rapid approaches to CF detection. This could be of great interest for molecular preimplanta- tion diagnosis for discriminating homozygous CF embryos from heterozygous and healthy embryos. In this case, the speed of the diagnostic procedure is critical in order to minimize the production of embryos that will be successfully tested and implanted (Ao et al, 1996). Other advantages of the methodology described in the present paper are (a) that it is a nonradioactive methodology and (b) that gel electrophoresis and/or dot-spot analysis are not required. Theoretically, this method is expected to be used in multiplex determinations. On the other hand, the format presented here is far from optimal for the charac- 
Table 3. Comparison of the Hybridization Efficiency of DNA and PNA Probes to Target PCA Products

\begin{tabular}{|c|c|c|c|c|c|c|}
\hline & \multicolumn{6}{|c|}{ Target: PCR products } \\
\hline & \multicolumn{2}{|c|}{$\begin{array}{l}\text { Normal } \\
(-/-)\end{array}$} & \multicolumn{2}{|c|}{$\begin{array}{l}\text { Heterozygous } \\
(-/ \mathrm{M}-\mathrm{W} 1282 \mathrm{X})\end{array}$} & \multicolumn{2}{|c|}{$\begin{array}{c}\text { Homozygous } \\
\text { (M-W1282X/M-W1282X) }\end{array}$} \\
\hline & RUfin-RUi & RUres-RUi & RUfin-RUi & RUres-RUi & RUfin-RUi & RUres-RUi \\
\hline \multicolumn{7}{|l|}{ DNA probes } \\
\hline N-W1282X 9-mer & 17 & 9 & 12 & 10 & 11 & 10 \\
\hline M-W1282X 9-mer & 10 & 11 & 10 & 9 & 9 & 11 \\
\hline N-W1282X 12-mer & 52 & 51 & 78 & 36 & 37 & 10 \\
\hline M-W1282X 12-mer & 59 & 16 & 70 & 32 & 39 & 41 \\
\hline \multicolumn{7}{|l|}{ PNA probes } \\
\hline N-W1282X 9-mer & 95 & 58 & 44 & 33 & 11 & 8 \\
\hline M-W1282X 9-mer & 22 & 14 & 51 & 42 & 119 & 81 \\
\hline
\end{tabular}

Table 4. Sensitivity of the 9-mer M-W1282X PNA Probe in Detecting PCR Products

\begin{tabular}{ccccccc}
\hline & \multicolumn{7}{c}{ \% of M-W1282X PCR products } \\
\cline { 2 - 6 } & 100 & 50 & 10 & 5 & 2.5 & 0 \\
\hline RUfin - RUi & $126 \pm 7.5$ & $76 \pm 4.6$ & $51 \pm 3.2$ & $31 \pm 2.1$ & $26 \pm 2.7$ & $22 \pm 3.5$ \\
\hline Results represent the RUfin - RUi values \pm SD of four independent experiments.
\end{tabular}

Results represent the RUfin-RUi values $\pm S D$ of four independent experiments.

terization of point mutations present in low percentages in heterogeneous tissue samples. For this reason, it would be a better choice to immobilize the PNA probes and inject PCR products, as recently proposed (Burgener et al, 2000). More work has to be done on this specific issue.

A final comment should be made on DNA microarray genotyping (Hacia et al, 1999; Wang et al, 1998). This novel high-throughput methodology allows simultaneous analysis of a large number of polymorphisms and is expected to be the major field of applied research (Eggers, 2000; Shi, 2001). Applications of chip-based technology include the simultaneous monitoring of thousands of genetic mutations in a single patient or thousands of patients for a single mutation. In this respect, a recent paper by O'Brien et al (2001) describes a SPR array biosensor based on spectroscopic imaging. Briefly, these authors developed a multi-element transduction system which combines conventional SPR spectroscopy with onedimensional SPR microscopy to create an effective platform for monitoring binding events on macro- or micro-patterned arrays created on disposable sensor chips (Nelson et al, 2001), thus allowing the analysis of several independent biospecific binding events simultaneously. Studies aimed at developing SPR-based arrayed biosensors have been undertaken by other research groups with very interesting preliminary results (Brockman et al, 2000; Nelson et al, 2001).

The data presented in our paper strongly support the use of PNA probes for the identification of point mutations in multiple arrayed samples, therefore introducing the possibility of high-throughput, SPR-based screening of point mutations. Additionally, we would like to emphasize that this is the first work on the use of SPR and biosensors for diagnosis of CF and, to our knowledge, is the first report showing an application of BIAcore analysis using PNA probes to detect point mutations in clinical applications and to discriminate between normal, heterozygous, and homozygous W1282X samples.

These results are in line with the concept that SPR technology performed with biosensors could be an integral part of a fully automated diagnostic system based on the use of laboratory workstations for DNA isolation and the preparation of PCR reactions (Mischiati et al, 1993).

\section{Materials and Methods}

\section{Synthetic Oligonucleotides and PNAs}

The nucleotide sequences of the normal N-W1282X and mutated M-W1282X oligonucleotide probes used in our experiments are reported in Figure 1. The CFTR W1282X region was amplified using the 5 '-end biotinylated CF1, 5'-AAGGAGAAATCCAGATCGA-3', and the CF2, 5'-TCACTATGGTGTCCACTCG-3', primers. These oligonucleotides were purchased from Pharmacia (Uppsala, Sweden) and purified by HPLC. PNAs were synthesized following a procedure described in the literature (Koch et al, 1997) partially modified on a (4-methylbenzhydryl)-amine-PS resin (CalbiochemNovabiochem, Laufelfingen, Switzerland) using commercial PNA monomers (Perseptive Biosystems, Framingham, Massachusetts) and o-(Benzotiazolyil)$\mathrm{N}, \mathrm{N}, \mathrm{N}^{\prime}, \mathrm{N}^{\prime}$-tetramethyluronium hexafluorophosphate (HBTU)/diisopropylethylamine as coupling reagent in $\mathrm{N}$-methyl-pyrrolidone/pyridine. The syntheses were performed on a $7.5-\mu \mathrm{mol}$ scale. The free PNAs were cleaved from the resin using a trifluoromethanesulfonic acid (TFMSA)/trifluoroacetic acid (TFA) mixture. 
HPLC purification was carried out on a $\mathrm{C}_{18}$ column (eluent: water-acetonitrile mixtures with $0.1 \%$ TFA; gradient: from $100 \%$ water to $100 \%$ acetonitrile in 25 minutes, flow $1 \mathrm{ml} /$ minutes); PNA N-W1282X (sequence: $\mathrm{H}$-TCCTCCACT- $\mathrm{NH}_{2}$ ); electrospray ionization (ESI) mass spectrometry: calculated $\mathrm{m} / \mathrm{z} 783.4$ $\left(\mathrm{MH}_{3}{ }^{3+}\right.$ ), found $\mathrm{m} / \mathrm{z}$ 783.8; PNA M-W1282X (sequence: $\mathrm{H}$-TCCTTCACT- $\mathrm{NH}_{2}$ ); ESI mass spectrometry: calculated m/z $788.8\left(\mathrm{MH}_{3}{ }^{3+}\right)$, found $\mathrm{m} / \mathrm{z} 788.3$.

\section{Melting Temperature Measurements}

The DNA sequences used in the hybridization experiments were purchased from Genset (Paris, France) (guaranteed oligonucleotides) and used without further purification. All hybrid samples reported were first incubated at $90^{\circ} \mathrm{C}$ for 5 minutes, then slowly cooled at room temperature. The total strand concentration for each sample was calculated using the following $\varepsilon_{260}$ $\left(\mathrm{mm}^{-1} \mathrm{~cm}^{-1}\right)$ for the four bases: T 8.8, C 7.3, A 10.4, $\mathrm{G}$ 11.7. All hybridization experiments were carried out in a $10 \mathrm{~mm}$ phosphate buffer, $100 \mathrm{~mm} \mathrm{NaCl}, 0.1 \mathrm{~mm}$ EDTA ( $\mathrm{pH} 7$ ). Melting curves were recorded by heating the samples $\left(1^{\circ} \mathrm{C} /\right.$ minute) and following the UV signal variation at $260 \mathrm{~nm}$ on a Perkin-Elmer Lambda Bio 20 spectrophotometer (Perkin Elmer, Norwalk, Connecticut). Melting temperatures were taken as the maximums of the first derivative of the melting curves.

\section{Polymerase Chain Reaction}

In each PCR reaction, 100 ng of human genomic DNA were amplified by Taq DNA polymerase using the CF1 and CF2 primers, amplifying the $\mathrm{W} 1282 \mathrm{X}$ region of the CFTR gene. PCR was performed in a final volume of $50 \mu \mathrm{l}$, containing $50 \mathrm{~mm} \mathrm{KCl}, 10 \mathrm{~mm}$ TRIS- $\mathrm{HCl}(\mathrm{pH} 8.8)$, $1.5 \mathrm{~mm} \mathrm{MgCl} 2,33 \mu \mathrm{M}$ dNTPs, and $0.33 \mu \mathrm{M}$ PCR primers by using $2 \mathrm{U} /$ reaction of Taq DNA polymerase. The 35 PCR cycles used were as follows: denaturation, 30 seconds, $94^{\circ} \mathrm{C}$; annealing, 30 seconds, $58^{\circ} \mathrm{C}$; and elongation, 20 seconds, $72^{\circ} \mathrm{C}$. The length of the CFTR PCR product was $89 \mathrm{bp}$.

\section{Surface Plasmon Resonance}

The BIAcore-1000 analytical system (BIAcore AB, Uppsala, Sweden) was used in all experiments. Sensor chips SA5 (research grade), precoated with streptavidin, and the running buffer HBS-EP, containing $10 \mathrm{~mm}$ HEPES (pH 7.4), $0.15 \mathrm{M} \mathrm{NaCl}, 3$ mM EDTA, and $0.005 \%(\mathrm{v} / \mathrm{v})$ Surfactant P20, were from BIAcore $\mathrm{AB}$. The experiments were conducted at $25^{\circ} \mathrm{C}$. The flow rate was $5 \mu \mathrm{l} /$ minute. Sensorgrams were analyzed with the BIAevaluation 2.1 software. Blank subtractions were performed in all of the experiments reported. To obtain an efficient capture of N-W1282X and M-W1282X probes onto the sensor chip, the well-documented streptavidin-biotin interaction was used (Leblond-Francillard et al, 1987). The sensor chip SA5 was used to capture 5 '-biotinylated normal and mutated W1282X oligonucleotides injected over the surface. After a pretreatment with a $10-\mu \mathrm{l}$ pulse of 50 $\mathrm{mm} \mathrm{NaOH}$, injections of $15 \mu \mathrm{l}$ of HBS-EP containing
$0.5 \mu \mathrm{g}$ of $\mathrm{N}-\mathrm{W} 1282 \mathrm{X}$ and M-W1282X biotinylated target oligonucleotide were performed in two different flow cells. The data obtained demonstrate that rapid capture of 400 to $600 \mathrm{RU}$ of mutated and normal W1282X target DNAs is obtained within 4 to 6 minutes. Hybridization was carried out at $25^{\circ} \mathrm{C}$, with a 4 $\mu \mathrm{l} /$ minute flow rate, in HBS-EP buffer. After hybridization, the sensor chips were regenerated by a $5-\mu l$ pulse of $50 \mathrm{~mm} \mathrm{NaOH}$.

\section{Sequencing of PCR Products}

PCR products were purified with Microcon-30 (Millipore Corporation, Bedford, Massachusetts) and sequenced using the BigDye terminator cycle sequencing kit and the $A B I$ Prism 377 DNA sequencer (PE Applied Biosystems, Foster City, California).

\section{Computer-Assisted Prediction of Secondary Structure of Single-Stranded PCR Products}

Secondary structures of single-stranded CFTR PCR products carrying both normal and mutated W1282X sequences were determined using the MFOLD software (version 3.0) developed by Zuker et al (1999) and Mathews et al (1999). The analysis was performed at a temperature of $25^{\circ} \mathrm{C}$ and at $0.15 \mathrm{M} \mathrm{NaCl}$.

\section{References}

Antonarakis SE (1998). Recommendations for a nomenclature system for human gene mutations. The Nomenclature Working Group. Hum Mutat 11:1-3.

Ao A, Ray P, Harper J, Lesko J, Paraschos T, Atkinson G, Soussis I, Taylor D, Handyside A, Hughes M, and Winston RM (1996). Clinical experience with preimplantation genetic diagnosis of cystic fibrosis (delta F508). Prenat Diagn 16: 137-142.

Baron H, Fung S, Aydin A, Bahring S, Luft FC, and Schuster $H$ (1996). Oligonucleotide ligation assay (OLA) for the diagnosis of familial hypercholesterolemia. Nat Biotechnol 14: 1279-1282.

Bernardino AL, Ferri A, Passos-Bueno MR, Kim CE, Nakaie CM, Gomes CE, Damaceno N, and Zatz M (2000). Molecular analysis in Brazilian cystic fibrosis patients reveals five novel mutations. Genet Test 4:69-74.

Bianchi N, Mischiati C, Feriotto G, and Gambari R (1993). Polymerase-chain reaction: Analysis of DNA/DNA hybridization by capillary electrophoresis. Nucleic Acids Res 21:35953596.

Bianchi N, Rutigliano C, Tomassetti M, Feriotto G, Zorzato F, and Gambari R (1997). Biosensor technology and surface plasmon resonance for real-time detection of HIV-1 genomic sequences amplified by polymerase chain reaction. Clin Diagn Virol 8:199-208.

Boat TF, Welsh MJ, and Beadudet AL (1989). Cystic fibrosis. In: Scriver CR, Beaudet AL, Sly WS, and Valle D, editors. The metabolic basis of inherited disease, 6th ed. New York: MacGraw-Hill, 2649-2680.

Brinson EC, Adriano T, Bloch W, Brown CL, Chang CC, Chen J, Eggerding FA, Grossman PD, lovannisci DM, Madonik AM, Sherman DG, Tam RW, Winn-Deen ES, Woo SL, Fung S, and lovannisci DA (1997). Introduction to PCR/OLA/SCS, a mul- 
tiplex DNA test, and its application to cystic fibrosis. Genet Test 1:61-68.

Brockman JM, Nelson BP, and Corn RM (2000). Surface plasmon resonance imaging measurements of ultrathin organic films. Annu Rev Phys Chem 51:41-63.

Burgener M, Sanger M, and Candrian U (2000). Synthesis of a stable and specific surface plasmon resonance biosensor surface employing covalently immobilized peptide nucleic acids. Bioconjug Chem 11:749-754.

Chen X, Livak KJ, and Kwok P-Y (1998). A homogeneous, ligase-mediated DNA diagnostic test. Genome Res 8:549556.

Clegg RM (1992). Fluorescence resonance energy transfer and nucleic acids. Methods Enzymol 211 353-388.

Dueholm KL and Nielsen PE (1997). Chemistry, properties and applications of PNA (Peptide Nucleic Acid). N J Chem 21:19-31.

Eggerding FA (2000). Fluorescent oligonucleotide ligation technology for identification of ras oncogene mutations. Mol Biotechnol 14:223-233.

Eggers M (2000). High-throughput microarray technology. Innov Pharm Technol 6:36-44.

Egholm M, Buchardt O, Christiensen L, Behrens C, Freier SM, Driver DA, Berg RH, Kim SK, Norden B, and Nielsen PE (1993). PNA hybridizes to complementary oligonucleotides obeying the Watson-Crick hydrogen-bonding rules. Nature 365:566-568.

Egholm M, Buchardt O, Nielsen PE, and Berg RH (1992). Peptide nucleic acids (PNA). Oligonucleotide analogues with an achiral peptide backbone. J Am Chem Soc 114:18951897.

Feriotto G, Lucci M, Bianchi N, Mischiati C, and Gambari R (1999). Detection of the $\Delta F 508$ (F508del) mutation of the cystic fibrosis gene by surface plasmon resonance and biosensor technology. Hum Mutat 13:390-400.

Gelfi C, Perego M, Righetti PG, Cainarca S, Firpo S, Ferrari $M$, and Cremonesi L (1998). Rapid capillary zone electrophoresis in isoelectric histidine buffer: High resolution of the poly-T tract allelic variants in intron 8 of the CFTR gene. Clin Chem 44:906-913.

Griffin TJ, Tang W, and Smith LM (1997). Genetic analysis by peptide nucleic acids affinity MALDI-TOF mass spectrometry. Nat Biotechnol 15:1368-1372.

Hacia JG, Fan JB, Ryder O, Jin L, Edgemon K, Ghandour G, Mayer RA, Sun B, Hsie L, Robbins CM, Brody LC, Wang D, Lander ES, Lipshutz R, Fodor SP, and Collins FS (1999). Determination of ancestral alleles for human singlenucleotide polymorphisms using high-density oligonucleotide arrays. Nat Genet 22:164-167.

Hyrup B and Nielsen PE (1996). Peptide nucleic acids (PNA), synthesis, properties and potential applications. Bioorg Med Chem 4:5-23.

Igloi GL (1999). Automated detection of point mutations by electrophoresis in peptide nucleic acid-containing gels. Biotechniques 27:798-808.

Jenkins FJ (1994). Basic methods for the detection of PCR products. PCR Methods Appl 3:S77-S82.

Jensen KK, Ørum H, Nielsen PE, and Nordén B (1997). Kinetics for hybridization of peptide nucleic acids (PNA) with
DNA and RNA studied with the BIAcore technique. Biochemistry 36:5072-5077.

Jonsson U, Fagerstam L, Ivarsson B, Johnsson B, and Karlsson R (1991). Real-time biospecific interaction analysis using surface plasmon resonance and a sensor chip technology. BioTechniques 11:620-627.

Kai E, Sawata S, Ikebukuro K, lida T, Honda T, and Karube I (1997). Novel DNA detection system of flow injection analysis (2). The distinctive properties of a novel system employing PNA (peptide nucleic acid) as a probe for specific DNA detection. Nucleic Acids Symp Ser 37:321-322.

Koch T, Hansen HF, Andersen P, Larsen T, Batz HG, Otteson $\mathrm{K}$, and Orum $\mathrm{H}$ (1997). Improvements in automated PNA synthesis using Boc/z monomers. J Peptide Res 49:80-88.

Leblond-Francillard M, Dreyfus M, and Rougeon F (1987). Isolation of DNA-protein complexes based on streptavidin and biotin interaction. Eur J Biochem 166:351-355.

Livak KJ, Flood SJA, Marmaro J, Giusti W, and Deetz K (1995). Oligonucleotides with fluorescent dyes at opposite ends provide a quenched probe system useful for detecting PCR product and nucleic acid hybridization. PCR Methods Appl 4:357-362.

Lizardi P, Huang X, Zhu Z, Bray-Ward P, Thomas D, and Ward D (1998). Mutation detection and single-molecule counting using isothermal rolling-circle amplification. Nat Genet 19:225-232.

Lyamichev V, Mast AL, Hall JG, Prudent JR, Kaiser MW, Takova T, Kwiatkowski RW, Sander TJ, de Arruda M, Arco DA, Neri BP, and Brow MA (1999). Polymorphism identification and quantitative detection of genomic DNA by invasive cleavage of oligonucleotide probes. Nat Biotechnol 17:292296.

Malmqvist M (1993). Biospecific interaction analysis using biosensor technology. Nature 361:186-187.

Mathews DH, Sabina J, Zuker M, and Turner DH (1999). Expanded sequence dependence of thermodynamic parameters improves prediction of RNA secondary structure. J Mol Biol 288:911-940.

Mischiati C, Fiorentino D, Feriotto G, and Gambari R (1993). Use of an automated laboratory workstation for isolation of genomic DNA suitable for polymerase chain reaction and allele-specific hybridization. BioTechniques 15:146-151.

Nelson BP, Grimsrud TE, Liles MR, Goodman RM, and Corn RM (2001). Surface plasmon resonance imaging measurements of DNA and RNA hybridization adsorption onto DNA microarrays Anal Chem 73:1-7.

Nielsen PE and Egholm M (1999). Peptide nucleic acids: Protocols and applications. Norfolk, UK: Horizon Scientific Press.

Nielsen PE, Egholm M, Berg RH, and Buchardt O (1991). Sequence selective recognition of DNA by strand displacement with a thymine-substituted polyamide. Science 254: 1497-1500.

Nilsson $\mathrm{P}$, Persson B, Larsson A, Uhlen M, and Nygren P-A (1997). Detection of mutations in PCR products from clinical samples by surface plasmon resonance. J Mol Recognit 10:7-17.

Nilsson P, Persson B, Uhlén M, and Nygren PA (1995). Real-time monitoring of DNA manipulations using biosensor technology. Anal Biochem 224:400-408. 
O'Brien MJ 2nd, Perez-Luna VH, Brueck SR, and Lopez GP (2001). A surface plasmon resonance array biosensor based on spectroscopic imaging. Biosens Bioelectron 16:97-108.

Ørum H, Nielsen PE, Egholm M, Berg RH, Buchardt O, and Stanley C (1993). Single base pair mutation analysis by PNA directed PCR clamping. Nucleic Acids Res 21:5332-5336.

Riordan JR, Rommens JM, Kerem B, Alon N, Rozmahel R, Grzelczak Z, Zielenski J, Lok S, Plavsic N, Chou JL, Drumm ML, Iannuzzi MC, Collins FS, and Tsui LC (1989). Identification of the cystic fibrosis gene: Cloning and characterization of complementary DNA. Science 245:1066-1073.

Rothschild CB, Brewer CS, Loggie B, Beard GA, and Triscott MX (1997). Detection of colorectal cancer K-ras mutations using a simplified oligonucleotide ligation assay. J Immunol Methods 206:11-19.

Saiki RK, Scharf S, Faloona F, Mullis KB, Horn GT, Erlich HA, and Arnheim N (1985). Enzymatic amplification of beta-globin genomic sequences and restriction site analysis for diagnosis of sickle cell anemia. Science 230:1350-1354.

Sawata S, Kai E, Ikebukuro K, lida T, Honda T, and Karube I (1999). Application of peptide nucleic acid to the direct detection of deoxyribonucleic acid amplified by polymerase chain reaction. Biosens Bioelectron 14:397-404.

Shi MM (2001). Enabling large-scale pharmacogenetic studies by high-throughput mutation detection and genotyping technologies. Clin Chem 47:164-172.

Shi MM, Bleavins MR, and de la Iglesia FA (1999) Technologies for detecting genetic polymorphisms in pharmacogenomics. Mol Diagn 4:343-351.

Shoshani T, Augarten A, Gazit E, Bashan N, Yahav Y, Rivlin Y, Tal A, Seret H, Yaar L, Kerem E, and Kerem B (1992). Association of a nonsense mutation (W1282X), the most common mutation in the Ashkenazi Jewish cystic fibrosis patients in Israel, with presentation of severe disease. Am J Hum Genet 50:222-228.

Tapp I, Malmberg L, Rennel E, Wik M, and Syvanen AC (2000). Homogeneous scoring of single-nucleotide polymorphisms: Comparison of the 5'-nuclease TaqMan assay and Molecular Beacon probes. Biotechniques 28:732738.

Tyagi S, Bratu DP, and Kramer FR (1998). Multicolor molecular beacons for allele discrimination. Nat Biotechnol 16:4953.

Vadgama P and Crump PW (1992). Biosensors: Recent trends, a review. Analyst 117:1657-1670.
Vidaud M, Fanen P, Martin J, Ghanem N, Nicolas S, and Goossens M (1990). Three point mutations in the CFTR gene in French cystic fibrosis patients: Identification by denaturing gradient gel electrophoresis. Hum Genet 85:446-449.

Wang DG, Fan JB, Siao CJ, Berno A, Young P, Sapolsky R, Ghandour G, Perkins N, Winchester E, Spencer J, Kruglyak L, Stein L, Hsie L, Topaloglou T, Hubbell E, Robinson E, Mittmann M, Morris MS, Shen N, Kilburn D, Rioux J, Nusbaum C, Rozen S, Hudson TJ, Lipshutz R, Chee M, and Lander ES (1998). Large-scale identification, mapping, and genotyping of single-nucleotide polymorphisms in the human genome. Science 280:1077-1082.

Wang $J$ (1998). DNA biosensors based on peptide nucleic acid (PNA) recognition layers. Biosens Bioelectron 13:757762.

Wang J, Nielsen PE, Jiang M, Cai X, Fernandes JR, Grant DH, Ozsoz M, Beglieter A, and Mowat M (1997a). Mismatchsensitive hybridization detection by Peptide Nucleic Acids immobilized on a quartz crystal microbalance. Anal Chem 69:5200-5202.

Wang J, Rivas G, and Cai X (1997b). Detection of point mutation in the p53 gene using peptide nucleic acid biosensor. Anal Chim Acta 344:111-118.

Weiler J, Gausepohl H, Hauser N, Jensen ON, and Hoeisel JD (1997). Hybridization based DNA screening on peptide nucleic acid (PNA) oligomer arrays. Nucleic Acids Res 25:27922799.

Wine JJ, Kuo E, Hurlock G, and Moss RB (2001). Comprehensive mutation screening in a cystic fibrosis center. Pediatrics 107:280-286.

Wittung P, Nielsen PE, Buchardt O, Egholm M, and Norden B (1994). DNA-like double helix formed by peptide nucleic acid. Nature 368:561-563.

Wong LJ, Wang J, Woo M, Hsu E, and Bowman CM (2000). A novel mutation detected by temporal temperature gradient gel electrophoresis led to the confirmative prenatal diagnosis of a Hispanic CF family. Prenat Diagn 20:807-810.

Wood SJ (1993). DNA-DNA hybridization in real time using BIAcore. Microchem J 47:330-337.

Zuker M, Mathews DH, and Turner DH (1999). Algorithms and thermodynamics for RNA secondary structure prediction: A practical guide. In: Barciszewski $\mathrm{J}$ and Clark BFC, editors. RNA biochemistry and biotechnology. NATO ASI Series. Dordrecht: Kluwer Academic Publishers, 11-43. 